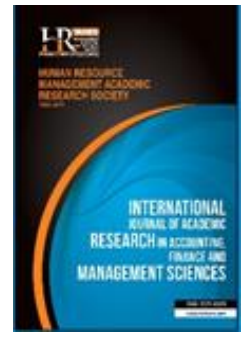

International Journal of Academic Research in Accounting, Finance and Management Sciences

Vol. 9, No.3, July 2019, pp. 295-299

E-ISSN: 2225-8329, P-ISSN: 2308-0337

(C) 2019 HRMARS

www.hrmars.com

To cite this article: Hudin, N.S., Hamid, A.B.A., Habidin, N.F., Mustaffa, W.S.W. (2019). Barrier Analysis of Supply

Chain Risk Management Adoption in Automotive Companies, International Journal of Academic Research in

Accounting, Finance and Management Sciences 9 (3): 295-299

http://dx.doi.org/10.6007/IJARAFMS/v9-i3/6521

(DOI: 10.6007/JARAFMS/v9-i3/6521)

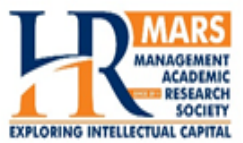

\title{
Barrier Analysis of Supply Chain Risk Management Adoption in Automotive Companies
}

\author{
Norlaile Salleh Hudin ${ }^{1}$, Abu Bakar Abdul Hamid², \\ Nurul Fadly Habidin ${ }^{3}$, Wan Salmuni Wan Mustaffa ${ }^{4}$ \\ ${ }^{1}$ Faculty of Management and Economics, Universiti Pendidikan Sultan Idris, Malaysia, \\ ${ }^{1}$ E-mail: norlaile@fpe.upsi.edu.my (Corresponding author) \\ 2 Putra Business School, Universiti Putra Malaysia, Malaysia
}

\begin{abstract}
This research identifies the barriers encountered by automotive component manufacturers in adopting supply chain risk management (SCRM). A qualitative case study method was employed at three purposely selected case companies by interviewing 10 senior managers. Data were analyzed using a thematic analysis. Results show that the automotive component manufacturers are prominently challenged by the level of understanding of SCRM which led to negative perceptions toward SCRM adoption. In conclusion, this study prepares automotive company managers with a foresight of SCRM adoption challenges so that sufficient planning could be developed for successful SCRM adoption.

Key words Supply Chain Management, Risk Management, Supply Chain Risk Management, Barriers, Automotive

Received: 03 Sep $2019 \quad$ C The Authors 2019

Revised: 15 Oct 2019 Published by Human Resource Management Academic Research Society (www.hrmars.com)

Accepted: 20 Oct 2019 This article is published under the Creative Commons Attribution (CC BY 4.0) license. Anyone may Published Online: $\quad 30$ Oct 2019 reproduce, distribute, translate and create derivative works of this article (for both commercial and non-commercial purposes), subject to full attribution to the original publication and authors. The full terms of this license may be seen at: http://creativecommons.org/licences/by/4.0/legalcode
\end{abstract}

\section{Introduction and literature Review}

The occurrence of supply chain risks (SCRs) such as poor quality supplies, supply shortages, and increased raw material prices have geared many researchers to study the effect of supply chain risk management (SCRM) adoption towards supply chain performance. For example, previous researchers found a positive effect of SCRM practices particularly risk identification and hedging towards the performance of manufacturing firms (Ochieng, 2019). In addition, companies which managed SCRs through collaboration and integral was found to lower their supply chain disruptions (Revilla and Saenz, 2017).

In line with the positive effect of SCRM implementation, automakers and original equipment manufacturers (OEMs) pressured the automotive component manufacturers to have SCRM in place (Franceschini et al., 2011; Singh, 2014) which was indicated by TS16949 compliance. TS16949 is a quality management standard for the automotive supply chain developed by Ford, General Motors and DaimlerCrysler. It was created to reduce risks in the automotive industry which are then translated into customer satisfaction. Therefore, TS16949 companies have to document their SCRM practice in terms of aspectimpact analysis and Failure Mode and Effect Analysis, among others, as proof that they are prepared against SCRs. Without TS16949, automotive component manufacturers have a slim chance to continue their business with automakers. Nevertheless, this research argues that involuntary SCRM implementation without a full understanding of SCRM concepts could be the source of barriers to a successful practice. 
Despite the strong move to reduce SCRs globally, not many have realized the impact of forcing the adoption of externally developed risk management standard to encourage widespread SCRM implementation. Earlier research found that organizations which had failed risk management were only concern with conforming to regulations (Collier et al., 2005) whereas other studies revealed that organizations which implemented risk management only to reap the reward for adopting good business practice and as an internal defense purposes also failed (Ericson, 2006). This situation is further supported by the Diffusion of Innovation Theory (DOI) which explained that an innovation developed internally has higher sustainability compared to an innovation developed externally (Rogers, 2010).

Based on these arguments, apparently, the right question which should be asked is why complying with externally developed SCRM is not enough to ensure a successful implementation? Prior researches revealed that companies were constrained by certain barriers to adopt or implement risk management such as the lack of knowledge (Chileshe and Kikwasi, 2013; Renault et al., 2016; Rostami et al., 2015), change management or negative attitude (Kallenberg, 2009; Moshesh et al., 2018; Yusuwan et al., 2008) and lack of top management support (Kumar Sharma and Bhat, 2014; Moshesh et al., 2018; Renault et al., 2016). However, none of these studies have shown that these barriers are interrelated and most of them are suspected to be symptoms rather than the actual problem. For example, a negative attitude towards SCRM and perceived high implementation cost could be the results of the lack of understanding. Table 1 summarizes the barriers to risk management adoption in past literature.

The lack of understanding is strongly argued to be the main issue in regards to SCRM failure. In a study of Canadian risk managers, it was found that firms were uncertain of how managing risks could create values (Kleffner et al., 2003). Furthermore, people had an unclear idea of the aim and purpose of implementing a risk management system. In Singapore, the senior management staff of the Chinese construction firms perceived the inadequate value of risk management to motivate the adoption of risk management (Zhao, 2015). Responding to this argument, case studies which enable in-depth investigation was employed to understand different kinds of barriers faced by companies in implementing their SCRM.

Table 1. Barriers to risk management adoption

\begin{tabular}{|c|c|c|c|c|c|c|c|c|}
\hline Author/Barriers & 1 & 2 & 3 & 4 & 5 & 6 & 7 & 8 \\
\hline Lack of understanding & / & & / & & / & I & & / \\
\hline Change management/Negative attitudes & I & / & & & & & & I \\
\hline Difficult & & / & & & & & l & / \\
\hline Time consuming & & & l & & & l & & \\
\hline Lack of guidelines & I & & & & I & & & I \\
\hline Expensive & & & / & & & l & & \\
\hline Poor collaboration & & & & / & & & & \\
\hline Lack of top management support & & & & l & & l & I & / \\
\hline
\end{tabular}

(1) Yusuwan et al. (2008); (2) Kallenberg (2009); (3) Chileshe and Kikwasi (2013); (4) Kumar Sharma and Bhat (2014); (5) Rostami et al. (2015); (6) Zhou et al. (2015); (7) Renault et al. (2016); (8) Moshesh et al. (2018)

\subsection{Research Aim}

The paper aims to explore the difference in the barriers faced by companies which developed their SCRM internally and externally. By understanding these barriers, companies can prepare against financial, workforce and capacity constraints more effectively.

\section{Methodology of Research}

This study employed a case study research method at three purposely selected small- and mediumsized automotive component manufacturers in Malaysia. These companies were selected based on several criteria such as; (1) organization that has good profitability, and (2) organization that has successfully manage supply chain issues. Vendor assessment reports were used to evaluate these criteria. Two of these companies (Company A and B) adopted TS16949 while the third company (Company C) developed SCRM 
internally. Altogether, 10 informants were interviewed and data collection was ended as the data reached saturation.

Majority of the informants were top managers including the senior manager, purchasing and procurement manager, logistic manager and quality management manager who had been working for the companies for about 25 years. The interview data were triangulated with researchers' observation and document analysis to increase research trustworthiness. The interviews were transcribed verbatim and analyzed by using a thematic analysis.

\section{Results and Discussions}

Several challenges have been identified in this study such as increased workloads, lack of English proficiency, lack of understanding, technical difficulties, high cost and time-consuming. However, unlike earlier studies which discussed the challenges in implementing SCRM separately, this study illuminates that these challenges are interrelated. On the overall, this study also found that these challenges are mostly rooted in the lack of understanding. Figure 1 summarizes themes revealed from the thematic analysis.

Despite the tendency of the informants to emphasize some of these challenges more than others, the analysis suggests that those challenges are often the symptoms rather than the real problem. For example, the informants of Company $A$ and $B$ strongly claimed that increasing workloads and technical difficulties were impeding this practice, nevertheless looking deeper into the context of Company $A$ and $B$, the actual problem and more serious issue is the lack of understanding about SCRM as purported by previous studies (Moshesh et al., 2018; Zhao, 2015; Darwish, \& Abdeldayem, 2019).

For Company A, the lack of understanding about managing SCRs has resulted in two situations. First, due to the top managers' lack of English language proficiency, they had trouble with understanding SCRM procedures outlined in the TS16949 standard and consequently, complying with this standard was regarded as substantially increasing their workload and time-consuming. This is further supported by their claim that preparing risk reports in English were burdensome.

Second, at least one of the top managers (Managing Director and the logistics manager) had yet come to understand the pressing need to manage SCRs which was suspected to be due to the absence of specific SCRM training, thus causing unawareness of SCRM potential benefits. For instance, convincing the Managing Director to invest in preventive countermeasures became particularly difficult because the Managing Director preferred to wait until a particular risk materialized before taking appropriate actions. Similarly, some of the managers we interviewed believed that this practice was only important when

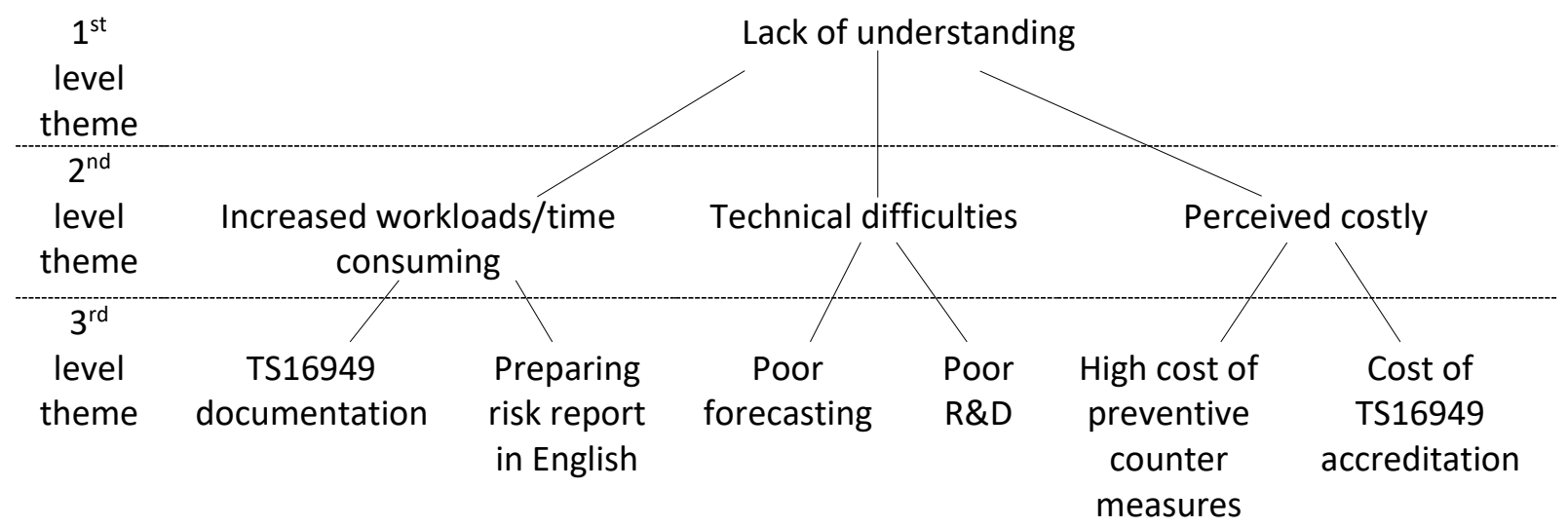

disruptions take place. For that reason, the lack of understanding is strongly believed to be the main problem that obstructing a successful implementation of SCRM at Company A.

Figure 1. Barriers to SCRM adoption

For Company B, they were not only faced the lack of understanding about SCRM which caused resistance to change but the lack of technical expertise which among other due to poor R\&D and poor forecasting also posed a challenge in preparing risk mitigation strategies. The warehouse manager explicated that employees were inclined to ignore procedures that had been developed to minimize risks because they did not see the value of SCRM. This lack of understanding of the SCRM benefits affects 
successful collaboration in managing SCRs.

Nonetheless, the lack of understanding about SCRM was not evident in Company $\mathrm{C}$. The managers in Company $\mathrm{C}$ admitted that they fully understand the need to adopt SCRM and supported their claims by explaining about adverse effects occurred as a result of poorly managed risks. Through such experiences, an organization learned to understand that managing risks could not be taken lightly, which led to fewer employees' resistance towards SCRM adoption and higher sustainability of SCRM in Company C. The only hindrance they encountered was in terms of time and cost constraints. This finding aligns with the DOI theory which emphasized the importance of developing an innovation internally to sustain it longer.

\section{Conclusions}

The study aims to explore the difference in the barriers faced by companies which developed their SCRM internally and externally. The results show that a lack of understanding about SCRM emerged as the main barrier towards the adoption of this practice. Due to this, the research informants perceived that SCRM increased their workloads and costly besides experiencing difficulty in mitigating and controlling SCRs. The barriers identified in this study can be used as references for better SCRM adoption. To achieve the potential benefits of SCRM, managers and automotive professionals need to address the lack of understanding of SCRM first. Instead of adopting SCRM for supplier qualification purpose, it is far more important to embrace the true meaning of adopting SCRM. Building such knowledge and understanding can be achieved through strong collaboration between academicians, industry professionals, and consultants.

\section{References}

1. Chileshe, N., \& Kikwasi, G. J. (2013). Perception of barriers to implementing risk assessment and management practices by construction professionals in Tanzania. Management, 1137, 1146.

2. Collier, P., Collier, P. M., \& Agyei-Ampomah, S. (2005). Management accounting-Risk and control strategy: Elsevier.

3.Darwish, S., \& Abdeldayem, M. M. (2019). Risk Management and Business Ethics: Relations and Impacts in the GCC. International Journal of Civil Engineering and Technology, 10(10), 489-504.

4. Ericson, R. (2006). Ten uncertainties of risk-management approaches to security. Canadian Journal of Criminology and Criminal Justice, 48(3), 345-356.

5. Franceschini, F., Galetto, M., Maisano, D. A., \& Mastrogiacomo, L. (2011). ISO/TS 16949: analysis of the diffusion and current trends. Proceedings of the Institution of Mechanical Engineers, Part B: Journal of Engineering Manufacture, 225(5), 735-745.

6. Kallenberg, K. (2009). Operational risk management in Swedish industry: Emergence of a new risk paradigm? Risk Management, 11(2), 90-110.

7. Kleffner, A. E., Lee, R. B., \& McGannon, B. (2003). The effect of corporate governance on the use of enterprise risk management: Evidence from Canada. Risk Management and Insurance Review, 6(1), 5373.

8. Kumar, S., Satyendra, \& Bhat, A. (2014). Supply chain risk management dimensions in Indian automobile industry: A cluster analysis approach. Benchmarking: An International Journal, 21(6), 10231040.

9. Moshesh, R., Niemann, W., \& Kotzé, T. (2018). Enterprise risk management implementation challenges: A case study in a petrochemical supply chain. South African Journal of Industrial Engineering, 29, 230-244.

10. Ochieng, B. (2019). Effect of Supply Chain Risk Management Practices on Performance of Manufacturing Firms in Kenya. Journal of International Business, Innovation and Strategic Management, 2(1), 14 - 30.

11. Renault, Berenger Y, Agumba, Justus N, \& Balogun, OA. (2016). Drivers for and obstacles to enterprise risk management in construction firms: a literature review. Procedia engineering, 164, 402-408. 
12. Revilla, E., \& Saenz, M. J. (2017). The impact of risk management on the frequency of supply chain disruptions: A configurational approach. International Journal of Operations \& Production Management, 37(5), 557-576.

13. Rogers, E. M. (2010). Diffusion of innovations: Simon and Schuster.

14. Rostami, A., Sommerville, J., Wong, I. L., \& Lee, C. (2015). Risk management implementation in small and medium enterprises in the UK construction industry. Engineering, Construction and Architectural Management, 22(1), 91-107.

15. Singh, N. (2014). Automotive industry response to its global QMS standard ISO/TS-16949 Globalization and Standards (pp. 121-142): Springer.

16. Yusuwan, N. M., Adnan, H., Omar, A. F., \& Kamaruzaman, J. (2008). Clients' perspectives of risk management practice in Malaysian construction industry. J. Pol. \& L., 1, 121.

17. Zhao, X. (2015). Enterprise risk management in international construction firms: drivers and hindrances. Engineering, Construction and Architectural Management, 22(3), 347-366. doi: 10.1108/ecam09-2014-0117 